\title{
Two new species of mealybugs (Hemiptera, Coccoidea, Pseudococcidae) from Iran
}

\begin{abstract}
Polystomophora arakensis Moghaddam and Phenacoccus salviacus Moghaddam are described and illustrated in detail from Iran. The species $P$. arakensis was collected from the roots of Atraphaxis sp. (Family: Polygonaceae) and $P$. salviacus was collected from the leaves of Salvia bracteata (Family: Labiatae). The genera Phenacoccus and Polystomophora are briefly reviewed and a key to the Iranian species of Phenacoccus is provided.

Riassunto - Two new species of mealybugs (Hemiptera, Coccoidea, Pseudococcidae) from Iran.

Sono descritti Polystomophora arakensis Moghaddam and Phenacoccus salviacus Moghaddam. P. arakensis è stato raccolto su radici di Atraphaxis sp. (Polygonaceae), mentre P. salviacus è stato rinvenuto su foglie di Salvia bracteata (Labiatae). Sono brevemente rivisti i generi Phenacoccus e Polystomophora ed è stata predisposta una chiave di classificazione delle specie di Phenacoccus dell'Iran.
\end{abstract}

Key words: scale-insects, mealybugs, new species, Iran.

\section{INTRODUCTION}

The genus Polystomophora Borchsenius is represented in the Palaearctic Region by only 2 species, P. ostiapluriana (Kiritshenko) and P. orientalis Matesova (Ter-Grigorian). The latter species, $P$. orientalis, has been recorded recently from Iran (Moghaddam et al., 2009).

The genus Phenacoccus is one of the largest genera of the family Pseudococcidae with about 180 species worldwide (Ben-Dov, 1994). Moghaddam (2009) has recently listed 3 species of Phenacoccus from Iran, and Moghaddam \& Bagheri (2010) reported P. solenopsis Tinsley from the southern part of Iran, and was probably introduced from Pakistan where is known as a serious pest of cotton. (Hodgson et al. 2008). Bodenheimer (1944) recorded P. sherbinovskyi Bodenheimer and Kozár et al. (1996) mentioned two more species of Phenacoccus from Iran. 


\section{METHODS}

The specimens were slide-mounted according to the method of Williams \& Granara de Willink (1992) and terminology follows that of Williams (2004). Body measurements are given in millimeters $(\mathrm{mm})$ and measurements of the microscopic characters in microns $(\mu \mathrm{m})$. The illustrations show the morphology of the dorsum on the left side and the venter on the right, with enlargements of important characters. These enlargements are not drawn to scale.

The specimens are deposited at the Iranian Research Institute of Plant Protection (IRIPP), Tehran, Iran.

Polystomophora arakensis Moghaddam sp. n. (Fig. 1)

Habit. It occurs on the root of the host plant.

Diagnosis. Appearance of adult female in life not recorded. Mounted female broadly oval, posterior end of body rounded, 2.4-2.6 mm long and 1.9-2.3 mm wide. Eyes 30.0-32.5 $\mu \mathrm{m}$ wide. Antennae 9 segmented, 330-340 $\mu \mathrm{m}$ long, apical segment 40-42 $\mu \mathrm{m}$ long, $30 \mu \mathrm{m}$ wide. Legs moderately developed; hind trochanter + femur 200-210 $\mu \mathrm{m}$ long, hind tibia + tarsus 230-240 $\mu \mathrm{m}$ long, hind claw 27-28 $\mu \mathrm{m}$ long, with a denticle; claw digitules longer than claws with a slightly expanded apex. Ratio of lengths of hind tibia + tarsus to hind trochanter + femur 1.04-1.06; ratio of lengths of hind tibia to tarsus 2.42, ratio of length of hind trochanter + femur to greatest width of femur about 3.3-3.5. Trochanter with 2 campaniform sensilla on each surface and with one long apical seta. Translucent pores present on posterior surface of hind femur, and on anterior and posterior surface of hind tibia. Tibia cylindrical, with two apical spines. Circulus present, $105 \mu \mathrm{m}$ wide, notched on each side, anterior margin slightly wider than posterior margin. Ostioles well developed, each lip with a few trilocular disc pores. Cerarii absent except anal lobe cerarii, each with 2 long slender setae, 35-55 $\mu \mathrm{m}$ long and a few trilocular pores. Anal ring rounded, about $75 \mu \mathrm{m}$ wide, lying at some distance from the apex, with two rows of pores, bearing 6 setae, each 30-35 $\mu \mathrm{m}$ long. Anal lobes inconspicuous, each lobe bearing an apical seta about $115 \mu \mathrm{m}$, a shorter seta about 72 $\mu \mathrm{m}$, and 1-2 long slender setae $50 \mu \mathrm{m}$ long.

Dorsum. Dorsal surface with long slender setae and flagellate setae. Multilocualr disc pores scattered across head and thoracic segments, and present on margin and midline of abdominal segments V- VII, and located across abdominal segments I-IV in 2 rows. Quinquelocular disc pores few, occurring on midline thoracic segments. Trilocular disc pores distributed on dorsum. Oral collar ducts present sparsely on dorsum.

Venter. Ventral surface with flagellate setae. Multilocular disc pores same as those on dorsum, present across head and thoracic segments, distributed across posterior and anterior edges of abdominal segments and posterior to vulva. Quinquelocular disc pores located in midline thoracic segments, present on anterior edges of abdominal segments I-III. Trilocular disc pores scattered over entire body. Oral collar tubular ducts dispersed throughout body to lateral edges. 


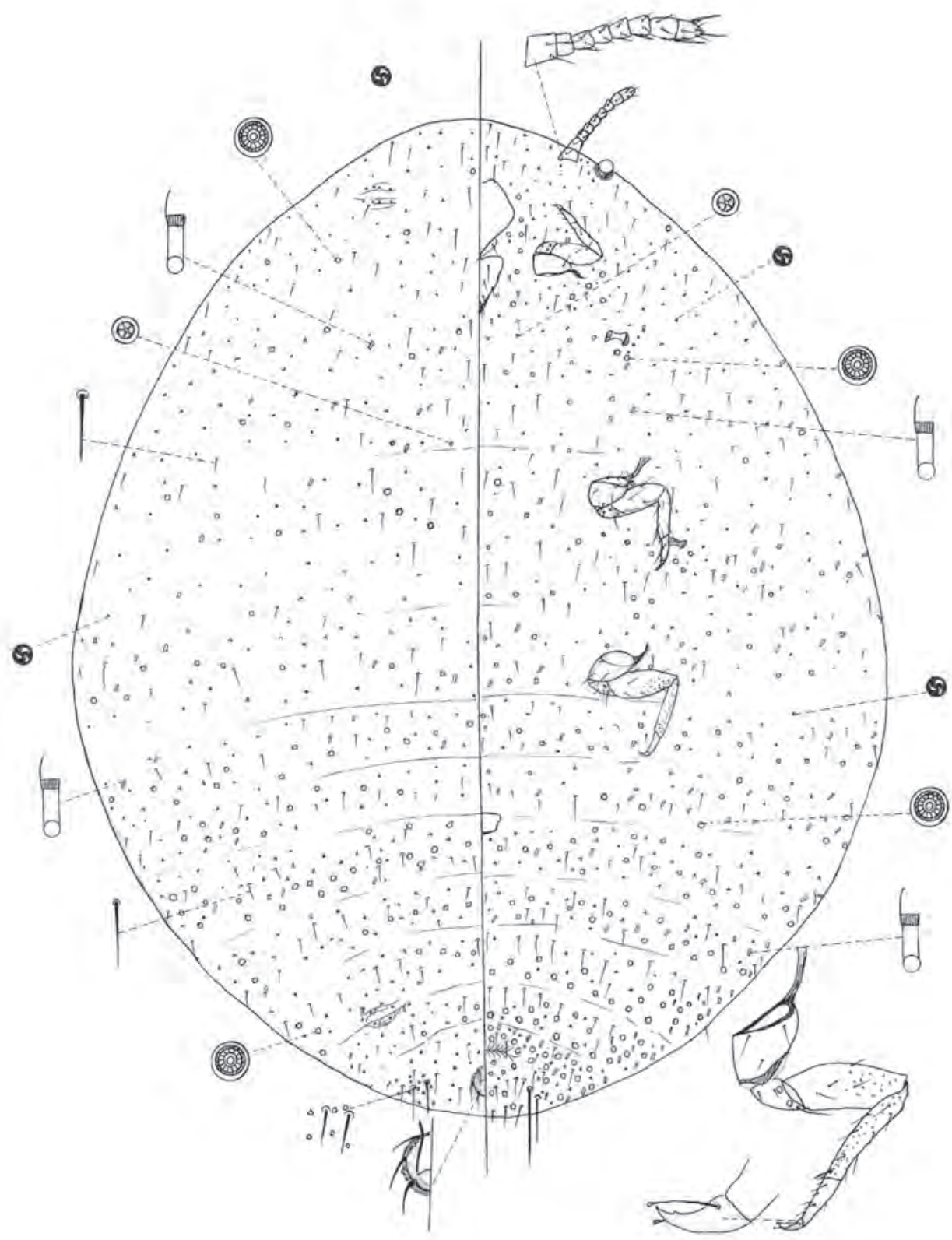

Fig. 1 - Polystomophora arakensis Moghaddam, sp.n. 


\section{COMMENTS}

The species $P$. arakensis differs from $P$. orientalis Matesova in having translucent pores on the hind femur and hind tibia; posterior end of body rounded and anal lobes inconspicuous. The mealybug $P$. arakensis differs from $P$. ostiaplurima (Kiritchenko) in having multilocular disc pores on the head, thorax and abdominal segments and also possessing one circulus.

\section{MATERIAL EXAMNED}

Holotype adult $q$, IRAN. Markazi province, Arak, from the roots of Atraphaxis sp., 10.x.2009, Leg. M. Alikhani (IRIPP).

Paratypes, IRAN. Same data as holotype, 1 adult female on the same slide as holotype and 14 adult females (IRIPP).

\section{ETYMOLOGY}

The name refers to Arak, the collecting site for the species.

Phenacoccus salviacus Moghaddam, sp. n. (Fig. 2)

Habit. It occurs on the leaves of the host plant.

Diagnosis. Appearance of adult female in life not recorded. Body of adult female on microscope slide elongate oval, 2.12-2.80 mm long. Anal lobes moderately developed, each ventral surface membranous, with an apical seta $95 \mu \mathrm{m}$ long and an inner seta 40 $\mu \mathrm{m}$ long. Antennae slender, each 415-440 $\mu \mathrm{m}$ long, 9 segmented. Legs well developed; hind trochanter + femur 270-300 $\mu \mathrm{m}$ long, hind tibia + tarsus 320-335 $\mu \mathrm{m}$ long, claw about $45 \mu \mathrm{m}$ long, with a denticle present. Ratio of lengths of hind tibia + tarsus to hind trochanter + femur 1.12-1.25. Ratio of lengths of hind tibia to tarsus 2.4-2.6. Translucent pores absent from hind legs. Circulus present between abdominal segments III and IV, $150 \mu \mathrm{m}$ wide. Ostioles well developed, each lip with 4-5 trilocular pores and a few setae. Anal ring about $65 \mu \mathrm{m}$ wide, bearing 6 setae, each about $110-118 \mu \mathrm{m}$ long. Cerarii numbering 12 pairs. Anal lobe cerarii with 2 conical setae, a few trilocular pores and 2 shorter setae, all situated on a lightly sclerotized area. Anterior cerarii each with 2 slightly shorter conical setae and 1 trilocular pore situated between setae. Posterior cerarii on abdominal segments V-VII, each with 2 setae and 2 trilocular pores, located on a slightly sclerotized area protruding from surface of derm.

Dorsum. Dorsal surface with slender, conical setae, mostly each $17.5 \mu \mathrm{m}$ long, some minute setae, each about $5 \mu \mathrm{m}$ long; some single setae with 1 trilocular pore at base of setal collar present on median, submedian and submarginal areas of dorsal segments. 1 median cerarius containing 2 setae and 2 trilocular pores at base, present on abdominal segment VII. Multilocular disc pores few, each about $7.5 \mu \mathrm{m}$ in diameter, present on posterior edges of abdominal segment VII. Oral collar tubular ducts, numbering 4-5, present across head, thorax and abdominal segments. 


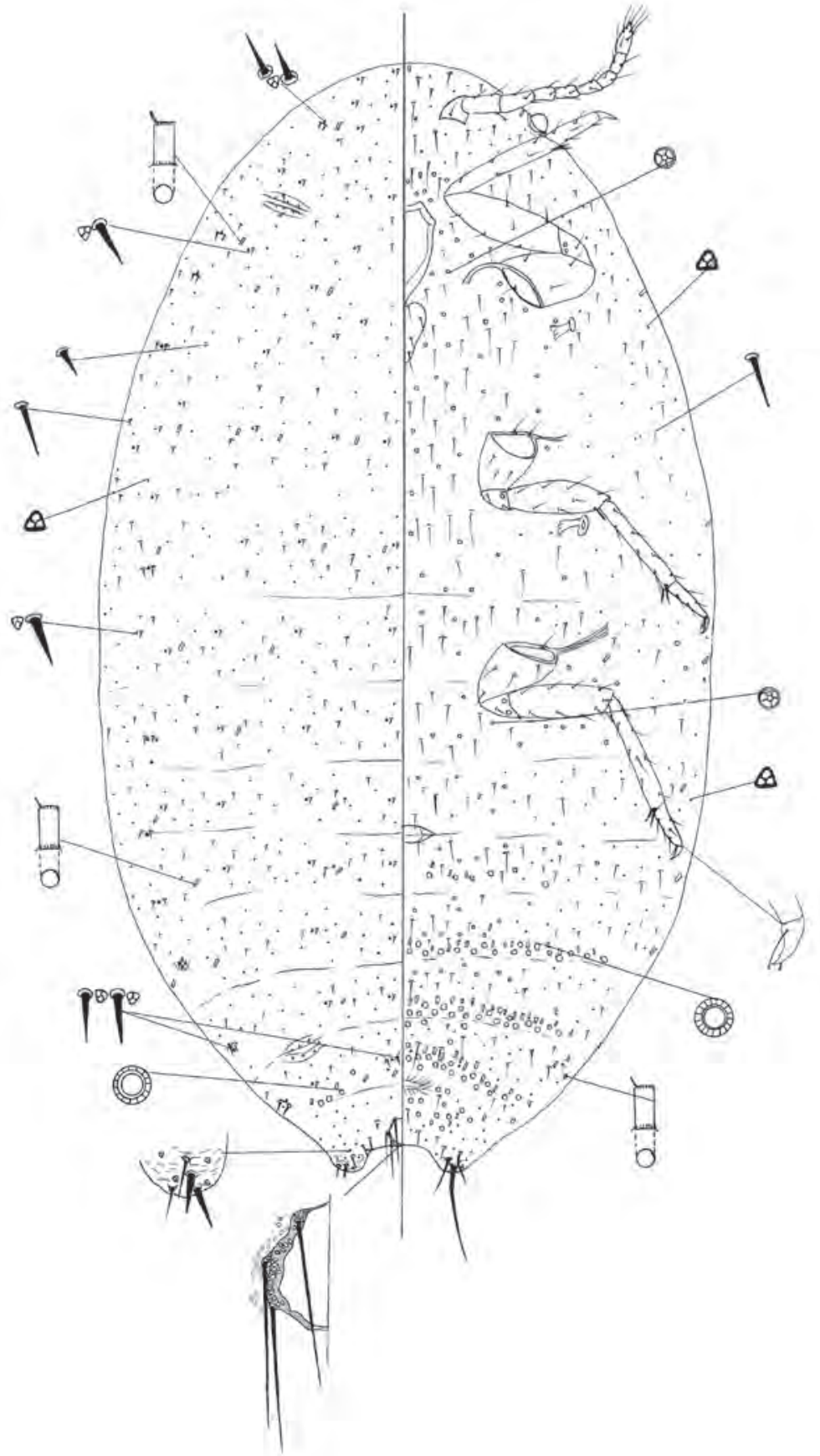

Fig. 2 - Phenacoccus salviacus Moghaddam sp.n. 
Venter. Ventral surface with long flagellate setae, except for some short conical setae situated around margins. Multilocular disc pores each about $7.5 \mu \mathrm{m}$ in diameter, present posterior to vulva, and on posterior edges of abdominal segments IV-VII, some on anterior edge of segment VII; multilocular pores never reaching margins. Trilocular pores sparse, present on margins and submargins of head, thorax and abdominal segments. Quinquelocular pores, each wider than a trilocular pore, present on midline and near midline of head, thorax and abdominal segments I - VI, also present on anterior edges of IV - VII abdominal segments. Oral collar tubular ducts, present along margins of thorax and anterior abdomen, single on thorax, and forming rows across abdominal segments V- VIII.

\section{COMMENTS}

The species $P$. salviacus differs from $P$. transcaucasicus Hadzibejli in having a few multilocular disc pores on abdominal segment VII; cerarii numbering 12 pairs, all cerarii with 2 slender, conical setae and 1 or 2 trilocular pores; also P. salviacus differs in having 1 median cerarius on abdominal segment VII and the presence of dorsal setae with 1 trilocular pore at the base of each setal collar, forming the rows across the dorsal segments.

\section{MATERIAL EXAMNED}

Holotype adult $\$$, IRAN. Markazi province, Arak, Shazand, Suraneh, on the leaves of Salvia bracteata, 10.x.2009, Leg. M. Alikhani (IRIPP).

Paratypes, IRAN. Same data as holotype, 8 adult females (IRIPP).

\section{ETYMOLOGY}

The name is based on the host plant name Salvia.

\section{Key to Iranian species of Phenacoccus}

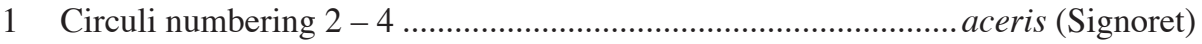

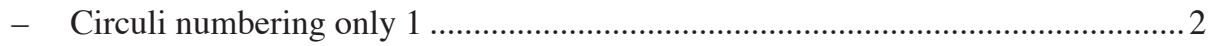

2 Cerarii numbering 18 pairs. Quinquelocular pores absent from venter. Dorsal setae lack trilocular pores at base of setal collar. Multilocular disc pores absent from dorsum

- Cerarii numbering 12 pairs. Multilocular present. Quinquelocular pores present on venter. Dorsal setae with 1 trilocular pore at base of setal collar. At most 2 - 4 multilocular disc pores present on dorsal abdominal segment VII ...salviacus $\mathrm{sp}$. $\mathrm{n}$.

3 Antennae normally 9-segmented. Multilocular disc pores on venter usually present only as far forward as segment VI, normally present at anterior edge of segment VII. Circulus often produced laterally, flaccid .solenopsis Tinsley 
- Antennae normally 8-segmented. Multilocular disc pores on venter usually present as far forward as segment IV, normally absent from anterior edge of segment VII. Circulus usualy small, slightly oval solani Ferris

\section{ACKNOWLEDGEMENTS}

We thank. Dr. D. J. Williams, the Natural History Museum, UK, for reading the manuscript and for their valuable comments and suggestions and our thanks also go to Dr. M. Parchami-Araghi (IRIPP) for his useful suggestions on the developing manuscript.

\section{REFERENCES}

BEN-Dov, Y. (1994) A systematic catalogue of the mealybugs of the world (Insecta: Homoptera: Coccoidea: Pseudococcidae and Putoidae) with data on geographical distribution, host plants, biology and economic importance. Intercept Limited, Andover, UK. 686 pp.

Hodgson, C.J., Abbas, G., ArIF, M.J., Saeed, S. \& Karar, H. (2008) Phenacoccus solenopsis Tinsley (Sternorrhyncha: Coccoidea: Pseudococcidae), an invasive mealybug damaging cotton in Pakistan and India, with a discussion on seasonal morphological variation. Zootaxa 1913: 1-35.

BODENHEIMER, F.S. (1944) Note on the Coccoidea of Iran, with description of new species. Bulletin de la Société Fouad ler d'Entomologie 28: 85-100.

KozÁr, F., FowjHAN, M.A. \& ZARRABI, M. (1996) Check- list of Coccoidea and Aleyrodoidea (Homoptera) of Afghanistan and Iran, with Additional Data to the Scale Insects of Fruit Trees in Iran. Acta Phytopathologica et Entomologica Hungarica 31 (1-2): 61-74.

Moghaddam, M. (2009) Insects of Iran, The List of Coccoidea in the Hayk Mirzayans insect Museum (2) Hemiptera: Coccoidea. Iranian Research Institute of Plant Protection, Tehran, Iran. $37 \mathrm{pp}$.

Moghaddam, M. \& Bagheri, M. (2010) A new mealybug pest in the south of Iran, Phenacoccus solenopsis Tinsley (Hemiptera: Coccoidea: Pseudococcidae). Journal Entomology Society of Iran (In press).

Moghaddam, M., Ram, P., Kamali, H. \& Bazoobandi, M. (2009) Polystomophora orientalis (Hemiptera: Coccoidea: Pseudococcidae), a new genus and species record for Iran. Journal of Entomological Society of Iran 29(1): 41.

Ter-Grigorian, M.A., (1973) Soft and armoured scales (Coccoidea) mealybugs (Pseudococcidae). Fauna of Armenian SSR. Izvestiya Akademii Nauk Armianskoi SSR. Erevan, 1-246.

Williams, D.J. (2004) Mealybugs of Southern Asia. The Natural History Museum, Kuala Lumpur: Southdene SDN. BHD. 896 pp.

Williams, D.J. \& GRANARA De Willink, M.C. (1992) Mealybugs of Central and South America, UK: CAB International. 635pp.

MasumeH MoghadDAM - Insect Taxonomy Research Department, Iranian Research Institute Plant of Protection, P.O. Box 19395-1454, Tehran, Iran. Moghaddam@iripp.ir

MAMUd AlikHANI - Azad University of Arak, P.O.Box 567- 38135, Arak, Iran. Mahmud.alikhani@gmail.com

Accepted 15 April 2010 